\title{
ITGB3 wt Allele
}

National Cancer Institute

\section{Source}

National Cancer Institute. IT GB3 wt Allele. NCI Thesaurus. Code C51174.

Human IT GB3 wild-type allele is located in the vicinity of $17 q 21.32$ and is approximately $59 \mathrm{~kb}$ in length. This allele, which encodes integrin beta- 3 protein, plays a role in the induction of platelet aggregation, cellular adhesion and cell-surface mediated signal transduction. 